\title{
Monitoring disturbance intervals in forests: a case study of increasing forest disturbance in Minnesota
}

\author{
David C. Wilson ${ }^{1}$ (D) $\cdot$ Randall S. Morin ${ }^{2} \cdot$ Lee E. Frelich $^{1} \cdot$ Alan R. Ek $^{1}$
}

Received: 27 September 2018 / Accepted: 8 July 2019/Published online: 29 July 2019

(C) INRA and Springer-Verlag France SAS, part of Springer Nature 2019

\begin{abstract}
- Key Message We develop analytical methods and explore trends in disturbance interval via systematic forest inventory observations at a bioregional scale.

- Context Our study spans the dynamic ecotone at the intersection of southern boreal forest, mixed hardwood forest, and tallgrass prairie ecosystems in Minnesota, USA. Disturbance-related tree mortality is a major driver of demographic and successional change in this bioregion.

- Aims We aim to provide reliable disturbance estimates for forest ecology and economic research.

- Methods We develop methods applicable to any region with systematic forest inventory observations. We assess disturbances observed by the United States Department of Agriculture-Forest Service Forest Inventory and Analysis program on permanent sample plots in Minnesota, USA.

- Results A roughly 50\% reduction in disturbance interval is apparent across all forest cover types and for most disturbance categories. The largest changes are for insect damage, disease, wind events, drought, and fire.

- Conclusion Publicly available forest inventory data captures the frequency of disturbance events across bioregional landscapes and over time. Our methods serve to highlight rapid changes in rates of damage to standing trees within the study area.
\end{abstract}

Keywords Forest inventory $\cdot$ Disturbance $\cdot$ Rotation interval $\cdot$ Field observation $\cdot$ Trends $\cdot$ Bioregional scale

\section{Introduction}

Disturbance plays an important role in the dynamics of natural forests. Biotic and abiotic changes can disrupt stand structure, resource availability, and/or the physical environment (Pickett and White 1985). Such disturbances can range spatially from small-scale to large-scale, stand-to-landscape replacing events. The rotation interval (RI) for disturbance (not necessarily stand replacing) varies widely with many factors including disturbance type, forest cover type, successional stage, geographic location, ownership, and management regime.

Handling Editor: Laurent Bergès

David C. Wilson

wils0602@umn.edu

1 Department of Forest Resources, University of Minnesota, Minneapolis, MN, USA

2 Forest Service, Forest Inventory and Analysis Unit, USDA, Newtown Square, PA, USA
Moreover, these rates of disturbance may vary with time, depending on long-term climate trends, anthropogenic land use patterns, wildlife population cycles, and other factors. In total, these disturbances drive successional change in the forest (Guyette and Kabrick 2002; Reilly and Spies 2016) by, for example, determining where and when canopy openings occur, which seedlings and sprouts grow free of browse, and the average time between disturbance events.

Increasing disturbances associated with climate change, invasive species (both plant and animal), invasive tree pests like emerald ash borer (Agrilus planipennis Fair), and diseases like Dutch elm disease (Ophiostoma ulmi Buism) have been reported in some parts of the world, including our study area. Extreme wind and precipitation-related events (e.g., either too much or too little) also appear to be on the rise. Indeed, it seems we must now plan for increased disturbance in the forest (Seidl et al. 2017). Thus, assessment of regional patterns and trends is needed.

Disturbance rates are relevant to timber production and harvest scheduling, but also to carbon sequestration, habitat management, biodiversity, and ecosystem services 
considerations. (For a few examples, see Rogers (1996), Thom and Seidl (2016), and Seidl et al. (2016).) Here, we use data from the ongoing cyclical forest inventory effort of the United States Department of Agriculture (USDA) Forest Service's Forest Inventory and Analysis Unit (FIA) to analyze recent disturbance trends. We believe this is also the first study to utilize the cyclic FIA data to estimate RIs for different types of disturbance.

Prior efforts to determine RIs have typically looked at a handful of disturbance and cover types across a modest geographic region using intensive field methods to assess dates and types of disturbance (Heinselman 1973; Frelich and Lorimer 1991; Frelich and Reich 1995). Those efforts typically examined tree data obtained using increment borer samples from the trunks of standing or downed trees. These samples allowed the assessment of fire dates, drought stress, times of release from suppression, or other indicators of disturbance across relatively long periods of one to four centuries.

However, forest inventory data can be used to assess disturbance-related mortality across large spatial extents (Reilly and Spies 2016). This research used data collected for periodic inventory efforts with a sample design unique to the Pacific Northwest Region. Others have used satellite imagery (Landsat) and light ranging and detection (lidar) to assess combined change from harvesting and natural disturbance (Vogeler et al. 2018; Matasci et al. 2018). The more recent, and nationally consistent, cyclic data collected by FIA (a 5-year cycle of data collection contributes to each estimate of forestland area in Minnesota) hold promise for informing similar analytic approaches. However, these data present various difficulties stemming from the timing and sequence of observations. We develop an approach, utilizing a broad-based representative forest inventory to inform a range of interests including estimates of natural and unplanned humaninduced disturbance. While our methods are applicable nationally and elsewhere, our specific objective was to devise a method for using FIA estimates of area disturbed to study RIs and trends for various types of natural disturbances across the forest. We use Minnesota as a case study to highlight the utility of the technique. We also test the hypotheses that disturbance rates (other than harvesting, which represents a planned treatment rather than a disturbance) have increased, decreased, or remained the same during the period of observation.

\section{Materials and methods}

\subsection{Study area}

A combination of natural and anthropogenic disturbance, coupled with periods of regrowth, has shaped Minnesota's forests over time. The exact nature of these dynamics varies widely depending upon timber markets, soils, physiography, and the specifics of disturbance leading to change. Frequent fires, windstorms, insect infestations, and diseases have all played a role in shaping Minnesota's forested landscape.

Heinselman $(1973,1996)$ spent much of his career mapping historic fires which shaped the mosaic of even-aged and multi-aged coniferous forests of Minnesota's Boundary Waters Canoe Area Wilderness. Fires also played a large role in shaping the forest following the removal of most white and red pine from accessible portions of Minnesota's northern forest between 1890 and 1920. These fires consumed the dense slash and damaged less desirable trees left on site. Aspen responded strongly to clearcuts followed by fire (Friedman and Reich 2005), dominating regrowth across much of Minnesota.

The famous blowdown of 1999, which affected a large swath of southern boreal forest, and mixed hardwood forest stretching from Minnesota across Southern Quebec, Canada, is another example of disturbance shaping Minnesota's forests. This massive straight-line windstorm toppled mature trees across 193,000 ha (an area roughly $48 \mathrm{~km}$ long and 6-18 km wide) in Minnesota alone (USDA Forest Service 2001). The blowdown released younger or smaller diameter stems of shade-tolerant species present in the understory. Regrowth in the path of the blowdown leans heavily towards northern white cedar (Thuja occidentalis L.), balsam fir (Abies balsamea (L.) Mill.), and black spruce (Picea mariana Mil.), a distinct change from the mature jack pine (Pinus banksiana (Lamb.)), red pine (Pinus resinosa Ait.), eastern white pine (Pinus strobus L.) and aspen (Populus tremuloides (Michx.), Populus balsamifera (L.), and Populus grandidentata (Michx.)) originally present on most of the landscape (Rich et al. 2007).

An explanatory mechanism for recent increases in insect outbreaks is their accelerated development rate and increased reproductive potential related to increasing temperatures (Porter et al. 1991; Ayres and Lombardero 2000). Additionally, the establishment of exotic insect and pathogen species in new locations (Aukema et al. 2010) may be more likely in a warmer climate (Virtanen and Neuvonen 1999; Lesk et al. 2017). The sporulation and colonization success of some forest pathogens may also respond to changes in temperature, precipitation, soil moisture, and relative humidity (Chakraborty et al. 1998). Hence, increasing temperatures also likely contribute to increased severity and shorter RIs for insect outbreaks, disease, fire, rot, and other events (Frelich and Reich 2010). Our methods may contribute to better understanding these processes and their implications for forest management. 


\subsection{FIA disturbance observations}

Disturbances recorded during plot visits (FIA methods are summarized in Appendix 2) include biotic and abiotic agents such as insects, diseases, animals, fire, weather, and geologic events affecting individual trees (Appendix 1) (O'Connell et al. 2017). Following FIA procedure, we do not consider intentional disturbances such as harvesting or thinning here. In that context, human-induced disturbance includes things like tree removal not associated with a planned harvest, brush clearing that damages or removes trees, or other unplanned human activities resulting in damage or mortality of the specified threshold.

Per FIA instructions, disturbances must have occurred since the last plot visit (5 years prior in Minnesota, but 7 or 10 years for some states) or within a cycle length (a defined 5year sample period) for new plots. FIA records the estimated year of disturbance along with the type. A disturbance must be at least 0.405 ha (1 acre) in size (clearly, this observation extends beyond the plot and includes assessment of conditions in the plot vicinity), with mortality or damage to $25 \%$ of the trees on the physical plot (e.g., the equivalent of at least one full subplot must be affected in most cases). Observations of disturbance are associated with the entire plot.

When a plot becomes inaccessible for any reason, it is replaced by a new observation (possibly from a different location) during the following field season. For this reason, observations of disturbances greater than 5 years old (Fig. 1 and Appendix 3 Table 4) can be recorded. There are two caveats:

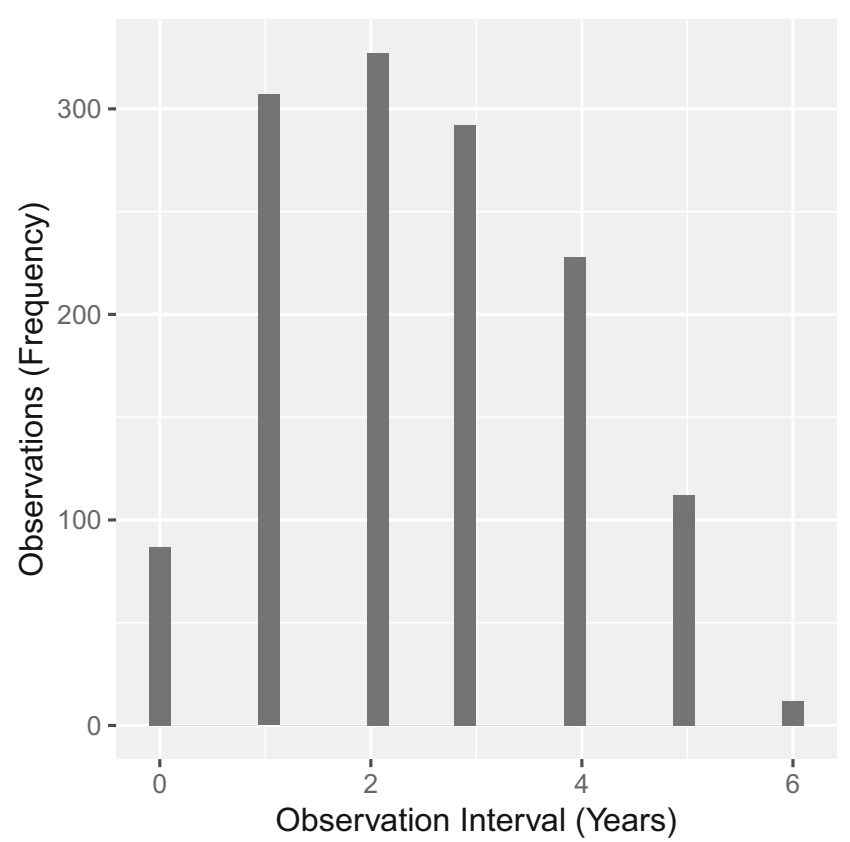

Fig. 1 Distribution of time delay for observation of disturbances via FIA inventory in Minnesota. Note the observation interval corresponding to the largest number of disturbance observations (e.g., 2 years following the event). We calculate the focal year as the annum in which disturbances observed in a given year were most likely to have occurred
(1) Observations from five sequential panels must be used to produce estimates of total and disturbed area. (2) A temporal lag between disturbance events and their observation limits the sightability, relevance, or completeness of some observations.

Recorded disturbances occurred between 1995 and 2016. Hence, we have a continuous set of observations, including any visible disturbance, spanning 21 years and $\sim 7$ million ha. Disturbances more than a few years old are clearly difficult to observe, with evidence of different disturbances likely persisting for different lengths of time. The record is reasonably complete for disturbance events occurring during the period 1998 to 2014 (Appendix 3 Table 4). Because most disturbances more than a few years old likely go unnoticed, disturbance RIs derived from these estimates are biased upwards (e.g., some level of disturbance went unnoticed).

\subsection{Model for estimating disturbance}

The standard defined by FIA is a 0.405 -ha (1-acre) disturbance affecting at least $25 \%$ of the trees present on and around a subplot. Thus, our prediction capability using these data is for disturbances affecting at least 0.405 ha.

At times, more than one disturbance occurs between visits to a plot. We counted these disturbances (142 records) as unique disturbance observations. We assigned these secondary disturbances a distinct disturbance code and year and counted the disturbed area a second time in summation of disturbed area. Correlation of repeated measures was ignored, but may be an issue for these 142 observations $(0.76 \%$ of our total plot observations; $142 / 18,789$ ), where the nature of a first disturbance may have altered susceptibility to a future disturbance. Regardless, a downward bias in estimates of disturbed area resulting from loss of disturbance visibility over time (Fig. 2) likely makes our estimates conservative in terms of the RI calculated.

The rotation (or recurrence) interval is the usual measure used to discuss the frequency with which a defined portion of the landscape will experience one or more disturbances (Swift and Ran 2012; Pickett and White 1985). The forestry literature further provides a distinction between the disturbance return interval (a point-based concept) and the rotation interval (an area-based concept) (Bond and Keeley 2005). Our methods rely on area estimation and therefore are parallel to the rotation interval concept and terminology. Comparison of area disturbed over time against total area (e.g., for a cover type, or for the forest as a whole) enables calculation of a RI for disturbance. In this case, the RI is the expected period required for each 0.405 ha in a specified cover type, or stratum, to experience one or more disturbances. We also discuss the RI for specific types of disturbance. Those intervals reference the entire forest, rather than area of a specific cover type, unless otherwise noted. 


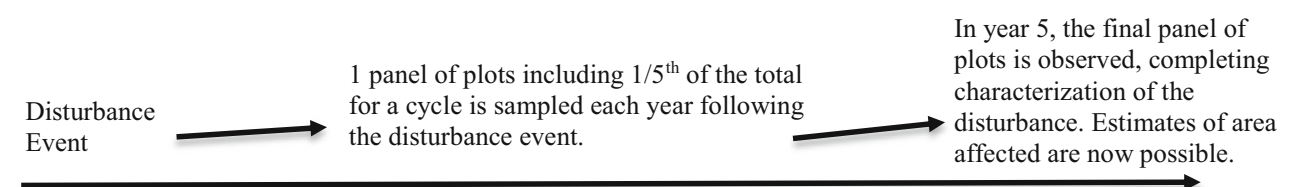

$\mathbf{0}$ (Inventory year) $\mathbf{1}(28.9 \%$ Observed) $\mathbf{2}(52.8 \%) \mathbf{3} \quad(74.2 \%) \mathbf{4}(90.9 \%) \quad \mathbf{5}(99.9 \%)$

Time Since Disturbance (Years)

Fig. 2 Timeline for observation of disturbances by FIA in Minnesota. Percentages indicate the cumulative proportion of total observations for a given disturbance year made with each panel of a 5-year cycle

For each cover type group, and for the forest as a whole, we calculated RI as:

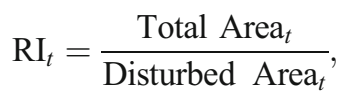

where $t$ corresponds to the focal year for reporting of disturbances, and Total Area $(t)$ is the then current estimate for total forest. In Minnesota, the focal period for observation of disturbed area lags 2 years behind the observation period for total area. An ordinary least squares regression model using focal year as the predictor and RI as the response was developed. We used Welch's $t$ test (Welch 1951) and linear regression (R Core Team 2018) to test for significance of changes in disturbance frequency over the period of observation.

To assess likely the variability of disturbance rates, we use the prop.test function (R Core Team 2018) to calculate the 95\% binomial confidence interval for each forest type group/ disturbance type group combination, and for the forest as a whole. The size of the set of responses generated at each iteration was proportional to (disturbed area sampled / mean expansion factor) for that forest cover type. This method ensures that perceived precision of the estimate is proportional to the number of disturbance observations contributing to the estimate for a forest type. In addition to trend analysis, we present cross-tabulations of:

1. Disturbance RI (all disturbances combined) by forest cover type,

2. Disturbance RI (all cover types combined) by disturbance type group, and

3. Disturbance RI by forest cover type-disturbance type group combinations.

\subsection{Statistical computing tools}

Here, we propose a reproducible methodology for estimating disturbance RIs. We compile our scripts (Appendix 3) as $\mathrm{R}$ markdown documents (.Rmd) constructed and run using \{knitr\} (Xie 2014, 2015, 2018) in RStudio (RStudio Team 2016). Scripts used to obtain our results summarized by disturbance group (Table 2) are available upon request. Similar methods were used to compile the disturbance data by forest cover type group (Table 3) and for the cross-tabulation of forest cover type group and disturbance type group (Appendix 3 Table 5).

\section{Results}

\subsection{Total disturbance rates: USDA-FIA inventory years 1999-2016}

We have records of 1780 disturbance events from 18,759 discrete observations (1999-2016) distributed across $\sim 7$ million ha of forestland. Of these, we used 1677 disturbance observations for events thought to have occurred from 1998-2014 to develop complete estimates of disturbance and to calculate RIs (Appendix 3 Table 4, bold). After excluding incomplete observations for events occurring at the extremes of the period of interest, we have a usable set of observations (Appendix 3 Table 4, shaded and bold) to develop estimates of disturbance RIs.

We depict frequency of disturbance as a RI by focal year (2001-2014) in Table 1 and Fig. 3. The expected RI declines from almost 23 years, to roughly 8 years over the course of observation. A linear model of the trend over time yields a highly significant slope $\left(p<0.0000012, R^{2}\right.$ $=0.8584$ ) suggesting an average change in overall RI of 1.28 years per year of observation. Similarly, one-sided Welch's $t$ test ( $p=0.01786$ with 172 degrees of freedom) suggests rejection of the null hypothesis that initial RIs for forest cover type-disturbance type combinations were either less than or equal to those observed at the end of the observation period. We therefore accept the alternative hypothesis that disturbance RIs have declined since 2001. Sample size limits our ability to estimate RI and confidence bounds for disturbance/cover type pairs with very few disturbance occurrences. Those with sufficient observations appear in Appendix 3 Table 5 along with binomial confidence bounds (e.g., RI.025 and RI.975). Examination of the temporal trend (Figs. 3, 4, and 5) shows that variation in the RI observed for different disturbances and cover types has decreased along with the interval. 
Table 1 Total area of forestland and disturbance for evaluation groups ${ }^{*}$ 2003-2016

\begin{tabular}{lllllllll}
\hline Cycle & $\begin{array}{l}\text { Sub- } \\
\text { cycle }\end{array}$ & Hectares sampled & Plots & Focal year & INVYR & Forestland hectares ${ }^{* *}$ & Ha $^{* * *}$ disturbed & Rotation interval \\
\hline 12 & 5 & $1,488,782$ & 1057 & 2001 & 2003 & $6,556,421$ & 288,808 & 22.70 \\
13 & 1 & $1,287,691$ & 1009 & 2002 & 2004 & $6,540,442$ & 341,726 & 19.14 \\
13 & 2 & $1,386,390$ & 1095 & 2003 & 2005 & $6,583,608$ & 326,639 & 20.16 \\
13 & 3 & $1,308,898$ & 1045 & 2004 & 2006 & $6,619,617$ & 299,187 & 22.13 \\
13 & 4 & $1,435,492$ & 1141 & 2005 & 2007 & $6,753,672$ & 326,228 & 20.70 \\
13 & 5 & $1,416,394$ & 1120 & 2006 & 2008 & $6,858,256$ & 340,360 & 20.15 \\
14 & 1 & $1,344,651$ & 1059 & 2007 & 2009 & $6,929,365$ & 341,382 & 20.30 \\
14 & 2 & $1,383,301$ & 1086 & 2008 & 2010 & $6,966,10$ & 483,884 & 14.40 \\
14 & 3 & $1,316,940$ & 1027 & 2009 & 2011 & $6,991,409$ & 579,250 & 12.07 \\
14 & 4 & $1,473,964$ & 1138 & 2010 & 2012 & $7,015,636$ & 644,765 & 10.88 \\
14 & 5 & $1,428,845$ & 1102 & 2011 & 2013 & $6,995,125$ & 730,027 & 9.58 \\
15 & 1 & $1,375,504$ & 1056 & 2012 & 2014 & $7,035,684$ & 819,511 & 8.59 \\
15 & 2 & $1,419,429$ & 1104 & 2013 & 2015 & $7,007,405$ & 800,999 & 8.75 \\
15 & 3 & $1,380,699$ & 1059 & 2014 & 2016 & $7,084,527$ & 896,469 & 7.90 \\
\hline
\end{tabular}

*Evaluation group refers to a collection of 5 sequential panels (e.g., sub-cycles). Each panel contributes $1 / 5$ th of the plot observations for a full evaluation period. The collection of all plots associated with an evaluation group form the basis for estimates of forested area

**Sampling error for total forestland hectares is approximately $0.52 \%$ ( $\pm 91,000 \mathrm{ha})$

***Sampling error for hectares disturbed varies from 3.3 to $6.0 \%$ ( $\pm 43,000-75,000$ ha)

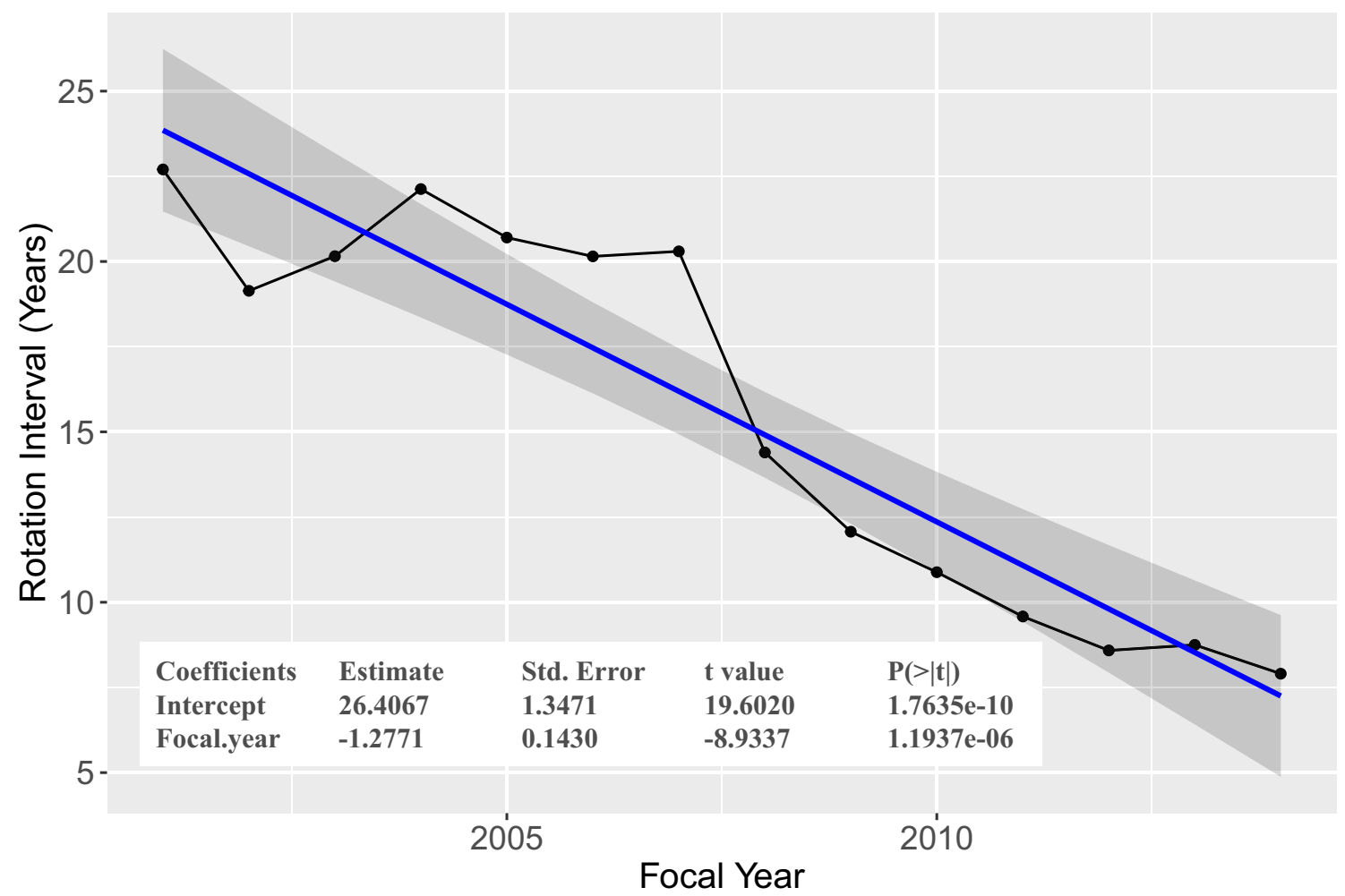

Fig. 3 Disturbance rotation interval (RI) trend, 2001-2014. The trend line is calculated as: $E[\mathrm{RI}]=26.41-1.28 \times \Delta$ Focal year, with variance weighted by number of plots contributing to each 5 -year estimate. The expected reduction in RI for each 1-year increase in focal year is 1.28 years $(p<0.0001)$ 


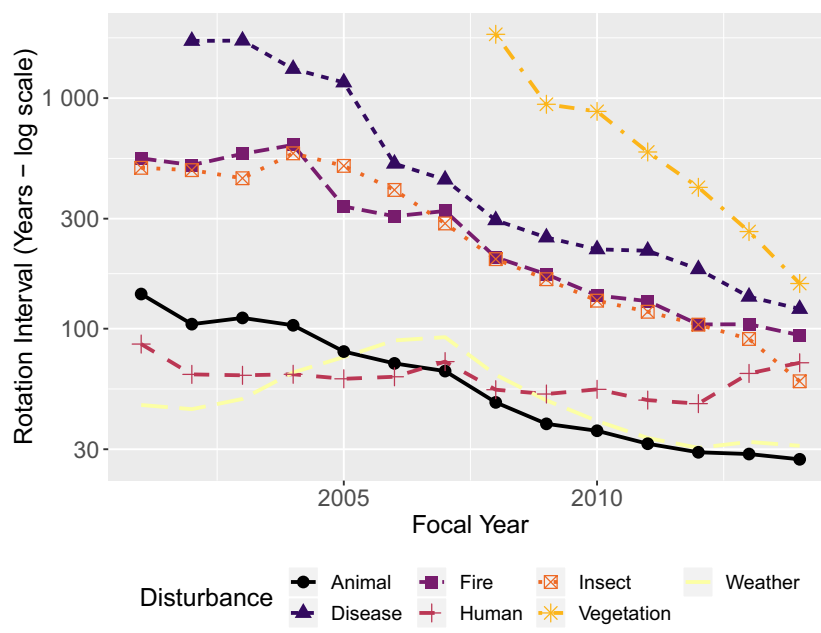

Fig. 4 Rotation interval (RI) (years) by disturbance type for focal years 2001-2014 (focal year refers to the annum in which most disturbances observed in the 5-panel evaluation group are thought to have occurred.). Geologic and unknown disturbances are omitted for visual simplicity

\subsection{Details by disturbance and forest cover type groups}

Frequency of disturbance and uncertainty associated with RIs varies greatly by disturbance type (Table 2 ). The most frequent disturbances were weather, animal, and human. RIs have generally declined for all disturbance types except human and geologic. The greatest decreases have occurred for disease, vegetation, insects, and fire (Fig. 4).

There was an almost 3-fold difference in disturbance RIs among forest cover types (Table 3). Although the aspen-birch group has suffered the greatest amount of absolute disturbance (hectares), both the oak-hickory and lowland hardwood groups have shorter RIs for disturbance. RIs have generally decreased over the study period for all forest type groups (Fig. 5). The RIs for total disturbance in a given cover type

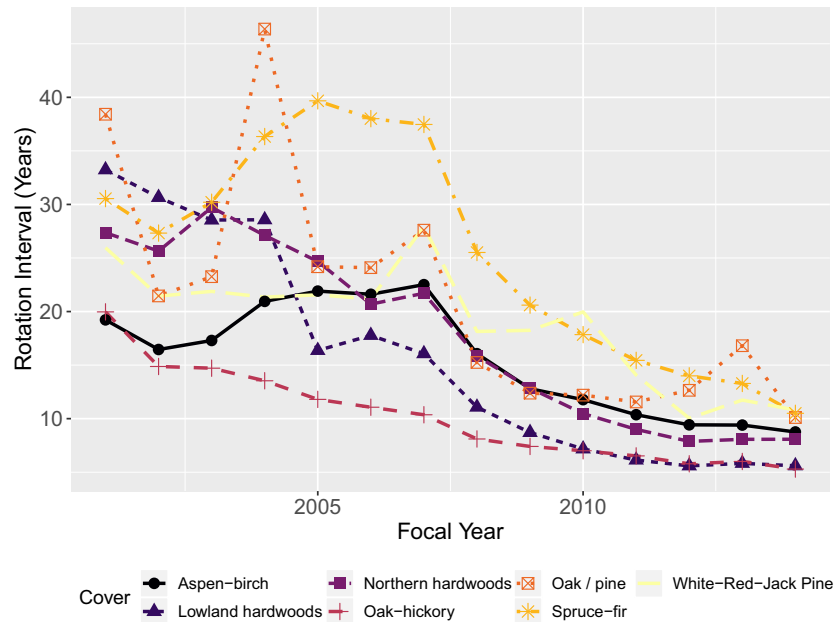

Fig. 5 Disturbance rotation interval (RI) for major forest cover types occurring in Minnesota
(Table 3) are much shorter than those for a given disturbance type (Table 2). For example, in order for the entire forest to experience insect damage or mortality to at least $25 \%$ of trees across at least an acre, we would need to wait approximately 180 years (Table 2). On the other hand, for all aspen to experience any kind of disturbance, we would only need to wait about 14 years (Table 3 ).

For reference, we estimate the RI for fire between 24 and 148 years (Appendix 3 Table 5) in the mixed pine woodlands of northern Minnesota with a mean of 60.5 years. Our overall estimate of RI for fire in the Border Lakes ecological subsection encompassing the Boundary Waters Canoe Area and Wilderness is 54.6 years.

\section{Discussion}

Previous research supports non-harvest tree fall recurrence intervals of 50-200+ years in mesic hardwood and mixed forests (Runkle 1982; Frelich and Lorimer 1991; Seymour et al. 2002). Frelich and Lorimer report 145-175 years for canopy residence times in sugar maple and hemlock, while at the 0.5 -ha scale, recurrence intervals range from 69 years for $>10 \%$ canopy removal to 1920 years for $>60 \%$ canopy removal, also similar to results from this study (using a 25\% canopy damage, not removal, threshold). Somewhat shorter RIs ( 129 years) predominate across Canada's western Boreal Shield (interpreted from White et al. 2017), which extends south into Minnesota's Border Lakes ecological subsection. Intervals are even shorter (50100 years) in the southern boreal forests of northern Minnesota (Heinselman 1973). These observations are consistent with the higher frequency of minor disturbance events compared with major events resulting in substantial tree mortality.

Results of the current study, as well as casual observation, support the conclusion that more frequent disturbances are now shaping Minnesota's forests. For example, emerald ash borer, oak wilt, Dutch elm disease, tent caterpillar, a severe drought, and several large wind and fire events have all occurred in Minnesota during the period analyzed.

Continued characterization of disturbance patterns using spatially and temporally representative data, like FIA, is needed to interpret changes in the forest, and processes affecting the forest, across larger spatial and temporal scales. The picture we can construct from FIA will improve as the length of time with consistently spaced repeat observations increases. The upper confidence bounds for many uncommon disturbance type/ cover type combinations (Appendix 3, Table 5) will likely decrease as we acquire additional observations. 
Table 2 Forest disturbance (1998-2014) observed by USDAFIA in Minnesota (1999-2015)

\begin{tabular}{llllll}
\hline Disturbance type & $\begin{array}{l}\text { Disturbance } \\
\text { group }\end{array}$ & $\begin{array}{l}\text { Frequency } \\
(1998-2014)^{*}\end{array}$ & $\begin{array}{l}\text { Rotation } \\
\text { interval } \\
\text { (years)** }\end{array}$ & $\begin{array}{l}\text { Hectares } \\
\text { affected per } \\
\text { year }\end{array}$ & $\begin{array}{l}\text { Hectares } \\
\text { affected per 5 } \\
\text { years }\end{array}$ \\
\hline No disturbance & 0 & 16,321 & N/A & $1,235,491$ & $6,177,453$ \\
Insect damage & 10 & 101 & 179.9 & 7441 & 37,203 \\
Disease & 20 & 47 & 363.0 & 3689 & 18,447 \\
Fire & 30 & 84 & 169.1 & 7916 & 39,580 \\
Animal & 40 & 347 & 50.5 & 26,525 & 132,624 \\
Weather & 50 & 415 & 41.8 & 32,046 & 160,232 \\
$\quad$ (wind/water/- & & & & & \\
$\quad$ temp) & 60 & 13 & 1341.3 & 1000 & 5000 \\
Vegetation & 70 & 7 & 2758.0 & 486 & 2431 \\
Unknown & 80 & 308 & 58.5 & 22,884 & 114,419 \\
Human & 90 & 3 & $6,051.3$ & 221 & 1103 \\
Geologic & All & 1325 & 13.1 & 102,208 & 511,038 \\
Disturbance & All Plots & 17,646 & - & $1,337,698$ & $6,688,491$ \\
Total & & & & & \\
$\quad$ Observations & & & & &
\end{tabular}

*For undisturbed plots, the observation period is 1999-2015. Calculation of RI considers disturbance observations from the period 1998-2014

**We calculate RI as total hectares/hectares disturbed across the entire forest
Disturbance frequencies fluctuate over time, especially those for large infrequent disturbances, making variability of estimates quite high. This complicates interpretation of the observed trend towards declining RIs. Nevertheless, the trend is significant, and the change is substantial $(\sim 50 \%)$, reaching very low recurrence intervals in the latest 5-year period (even considering the confidence intervals). This trend may indicate a shift in response to warming climate (Dale et al. 2001; Seidl et al. 2017), or change in other factors including anthropogenic species introductions/extinctions, fire suppression/ignition, or land clearing for agriculture. These changes could also be part of a natural fluctuation. If it is a regime shift characterized by increased frequency of storms, droughts, and invasive insect pests and tree diseases, it may still be temporary and shift back to longer
Table 3 Total disturbance by forest cover type group

\begin{tabular}{|c|c|c|c|c|c|c|}
\hline $\begin{array}{l}\text { Forest type } \\
\text { group }\end{array}$ & $\begin{array}{l}\text { Group } \\
\text { code }\end{array}$ & Plots ${ }^{*}$ & $\begin{array}{l}\text { Hectares } \\
\text { sampled }\end{array}$ & $\begin{array}{l}\text { Hectares } \\
\text { disturbed }\end{array}$ & $\begin{array}{l}\text { Mean } \\
\text { hectares }\end{array}$ & $\begin{array}{l}\text { Rotation } \\
\text { interval }\end{array}$ \\
\hline Aspen-birch & 900 & 6818 & $8,762,894$ & 645,960 & $2,577,322$ & 13.6 \\
\hline Spruce-fir & 120 & 4060 & $5,203,921$ & 254,643 & $1,530,565$ & 20.4 \\
\hline Oak-hickory & 500 & 2137 & $2,773,439$ & 326,826 & 815,717 & 8.5 \\
\hline L. hardwoods & 700 & 1609 & $2,049,837$ & 207,626 & 602,893 & 9.9 \\
\hline N. hardwoods & 800 & 1231 & $1,575,893$ & 112,888 & 463,498 & 14.0 \\
\hline W-R J Pine & 100 & 997 & $1,339,501$ & 82,050 & 393,971 & 16.3 \\
\hline Oak-pine & 400 & 302 & 402,672 & 23,164 & 118,433 & 17.4 \\
\hline Non-stocked & 999 & 246 & 315,721 & 43,691 & 92,859 & 7.2 \\
\hline $\begin{array}{l}\text { Other } \\
\text { hardwoods }\end{array}$ & 960 & 209 & 269,682 & 39,334 & 79,318 & 6.9 \\
\hline $\begin{array}{l}\text { Other } \\
\text { softwoods }\end{array}$ & 170 & 20 & 25,694 & 1349 & 7557 & 19.0 \\
\hline All disturbed & & 1610 & $1,737,531$ & $1,737,531$ & 511,038 & 13.1 \\
\hline $\begin{array}{l}\text { All } \\
\text { undisturbed }\end{array}$ & & 16,019 & $20,981,722$ & 0 & $6,171,095$ & N/A \\
\hline All plots & & 17,629 & $22,719,253$ & $1,737,531$ & $6,682,133$ & 1.0 \\
\hline
\end{tabular}

*17 plots (roughly 21,500 ha) corresponding to Scotch pine ( 8 plots) and exotic hardwoods ( 9 plots) were omitted from the summary presented here, as all such plots appeared undisturbed 
recurrence intervals because susceptible trees die off, in a self-regulating, homeostatic process described by Runkle (1982).

The Generic Environmental Impact Statement on Timber Harvesting in Minnesota (Jaakko Pöyry Consulting, Inc. 1992), as well as more recent crosstabulations of cover type area (Wilson and Ek 2018), shows that there is a regular and somewhat predictable exchange of area among cover types. Disturbance interacts with age-related growth and susceptibility patterns to determine the success of individual stems and hence the direction and velocity of forest succession. This hypothesis is supported by much experimental and observational data and may be corroborated through comparison of disturbance rates against successional and demographic changes among forest cover types and ecoregions. To this end, we enable assessment of disturbance, as well as differences among forest cover types, across relevant spatial and temporal scales.

\section{Conclusions}

Further investigation of disturbance in other regions may corroborate the trend towards shorter disturbance intervals observed here (e.g., Reilly and Spies 2016) as part of a broader pattern, or show that they are a local phenomenon. Trends reported here appear to be both meaningful in terms of their magnitude and are significant from a statistical perspective. Methods presented are transferrable to other states or regions monitored by systematic forest inventory and may aid in illustrating the spatial and temporal scale of observed changes. Finally, regional or national application of this methodology could help estimate RIs for different forest and disturbance types across their geographic ranges.

Acknowledgments This research has been supported by the University of Minnesota, Department of Forest Resources, the Interagency Information Cooperative through the Minnesota Department of Natural Resources, and the USDA Forest Service Northern Research Station FIA Unit. Special thanks to stackoverflow.com, crossvalidated.com and the R user community for excellent coding examples and support.

Contributions Alan Ek provided the research direction and early interpretations of disturbance observations recorded by USDA-FIA. Alan's participation in early discussions on how to use the FIA data for disturbance analysis was critical to sorting through the methodology involved. Alan also provided substantial review and critical expertise in honing the final manuscript.

Lee Frelich provided the disturbance analysis and forest ecology expertise to couch the current research in terms of past and ongoing efforts to assess return intervals for forest disturbance. Lee's descriptions of the study area and the relevant disturbance ecology were also very helpful in outlining the natural history of the study area and relevance of the research.
Randall Morin provided the FIA insider view of the data collected, field procedures, and past analyses using FIA data for area estimation related to disturbance. Randall also participated in several rounds of review and contributed substantially to the final wordsmithing.

David Wilson is the lead author and performed all of the scripting and analysis presented in the current paper. David wrote early drafts, provided synthesis of multiple authors' contributions, and developed the methodology and explanations presented herein.

Data availability The datasets generated and/or analyzed during the current study are available in the Forest Inventory and Analysis Database.

June 20, 2019. Forest Inventory and Analysis Database, St. Paul, MN: U.S. Department of Agriculture, Forest Service, Northern Research Station. https://apps.fs.usda.gov/fia/datamart/datamart.html

All scripts noted in this report are available from the corresponding author upon request.

\section{Compliance with ethical standards}

Conflict of interest The authors declare that they have no conflict of interest.

\section{Appendix}

\section{Appendix 1. Disturbance codes and descriptions recorded by USDA-FIA (O'Connell et al. 2014)}

\begin{tabular}{lll} 
Code & Group & Description \\
\hline 0 & 0 & No visible disturbance \\
10 & 10 & Insect damage \\
11 & 10 & Insect damage to understory vegetation \\
12 & 10 & Insect damage to trees, including seedlings and saplings \\
20 & 20 & Disease damage \\
21 & 20 & Disease damage to understory vegetation \\
22 & 20 & Disease damage to trees, including seedlings and saplings \\
30 & 30 & Fire damage (from crown and ground fire, either \\
& & prescribed or natural) \\
31 & 30 & Ground fire damage \\
32 & 30 & Crown fire damage \\
40 & 40 & Animal damage \\
41 & 40 & Beaver (includes flooding caused by beaver) \\
42 & 40 & Porcupine \\
43 & 40 & Deer/ungulate \\
44 & 40 & Bear (core optional) \\
45 & 40 & Rabbit (core optional) \\
46 & 40 & Domestic animal/livestock (includes grazing) \\
50 & 50 & Weather damage \\
51 & 50 & Ice \\
52 & 50 & Wind (includes hurricane, tornado) \\
53 & 50 & Flooding (weather induced)
\end{tabular}




\begin{tabular}{lll}
54 & 50 & Drought \\
60 & 60 & Vegetation (suppression, competition, vines) \\
70 & 70 & Unknown/not sure/other (include in notes) \\
80 & 80 & $\begin{array}{c}\text { Human-induced damage — any significant threshold of } \\
\text { human-caused damage not described in the } \\
\end{array}$ \\
& \multicolumn{2}{c}{ TREATMENT codes } \\
90 & 90 & Geologic disturbances \\
91 & 90 & Landslide \\
92 & 90 & Avalanche track \\
93 & 90 & Volcanic blast zone \\
94 & 90 & Other geologic events \\
95 & 90 & Earth movement/avalanches
\end{tabular}

\section{Appendix 2. USDA-FIA sampling protocol and analysis}

FIA conducts an inventory of forest attributes across the USA. Early inventories represented a periodic effort (e.g., FIA completed a snapshot inventory every $10-15$ years). Recent methods involve an ongoing annual effort in which data collected from five overlapping panels of plots provides a complete snapshot of the state's forests. The sampling design uses a tessellation of the land base into hexagons approximately 2428 ha in size with at least one permanent plot established in each hexagon. Tree and site attributes are observed for plots on forestland. At each plot, observations and measurements are made on four 7.32-m fixed-radius subplots (Bechtold and Patterson 2005). A bounding box around the subplots (arranged in an equilateral triangle with a central subplot) encompasses approximately 0.3 ha. A $17.96-\mathrm{m}$ radius macro-plot is defined around each subplot for standardization of the area used in reporting stand and vicinity level observations. Here, we focus on observations of disturbances (Section 2.1) made between 1999 and 2016.

Over 5 years, data is collected from approximately 6000 permanent sample plots located on forest lands throughout Minnesota. Plots are divided into 5 annual panels, each of which represents a sparse, but representative sample of the forest. When combined across a full 5-year cycle, these data provide a detailed look at the regional forest resource. These data are compiled, analyzed, managed, and publicly distributed as a PostgresSQL 10 database (Miles 2017). Inventory data can be accessed via: https://apps.fs.usda.gov/fia/datamart/ datamart.html. Statistical methods used by FIA to produce forest summaries are described by Bechtold and Patterson (2005) and implemented by Miles (2017). FIA methods are largely replicated here. Statistical methods described by Bechtold and Patterson (2005) detail a moving average method, which we use here to blend panels across cycles, creating a rolling estimate of forest and disturbed area.

We processed the raw FIA data in R ( $\mathrm{R}$ Core Team 2018) for efficiency and flexibility. Total area of disturbed and undisturbed forestland was summarized for each 5-year period. We used a dual moving window analysis (in the temporal sense) to produce representative estimates of base (20032016) and disturbed (2002-2015) forestland area for reporting periods ending between 2003 and 2016. Bechtold and Patterson (2005) detail methods for calculation of a moving average across multiple panels and cycles. The number of disturbance events observed at each time step was also recorded to illustrate the sequence of events leading to observation of a disturbance during plot visits over the subsequent 5 years.

Auto-correlation potentially arising from repeated measurement of plots over time is not a large issue for the current analysis. We view the FIA sampling scheme for disturbance as a case of change detection involving observation of fixed permanent plots (with limited partial replacement due to inaccessibility, denied entry, or change to a non-forested condition) systematically placed across the area of interest. Thus, we assume the occurrence of a disturbance on any given plot has no effect on the probability of a future event. However, for growth and yield, and in limited cases where one disturbance might change future susceptibility to a secondary disturbance (e.g., a blowdown, beetle kill, or severe drought), correlation effects resulting from repeated measurement of plots should be considered.

\section{Appendix 3. Brief example using the Bache/Wickham piping procedure and workflow}

We take advantage of several functions and tools provided by the R user community, especially the suite of packages included in \{tidyverse\} (Wickham 2017a, b). This suite of interlocking packages includes \{ggplot2\} (Wickham 2009), \{dplyr\} (Wickham et al. 2017a, b), \{tidyr\} (Wickham 2017a, b), \{readr\} (Wickham et al. 2017a, b), \{purrr\} (Henry and Wickham 2017), and \{tibble\} (Müller and Wickham 2017). Tidyverse also uses custom notation from the \{magrittr\} package (Bache and Wickham 2014) for directing data to a specified workflow and output using efficient methods via the " $\%>\%$ ", or pipe, operator. Because \{tidyverse allows us to define several processes within the "summarize" wrapper function, we can create a data output tailored to our analytical needs. A brief example showing assignment to an output, direction of data to a function, and definition of the output follows. 
Table 4 Disturbance matrix for Minnesota showing observations by disturbance and inventory year. Bold shaded records were included in the analysis. Ongoing disturbances can result from longer-term events like drought, invasion by competing vegetation, or repeated deer browse over many years. The last 2 digits of the disturbance year are used across the top of the table to show timing of disturbances

\section{Disturbance Year}

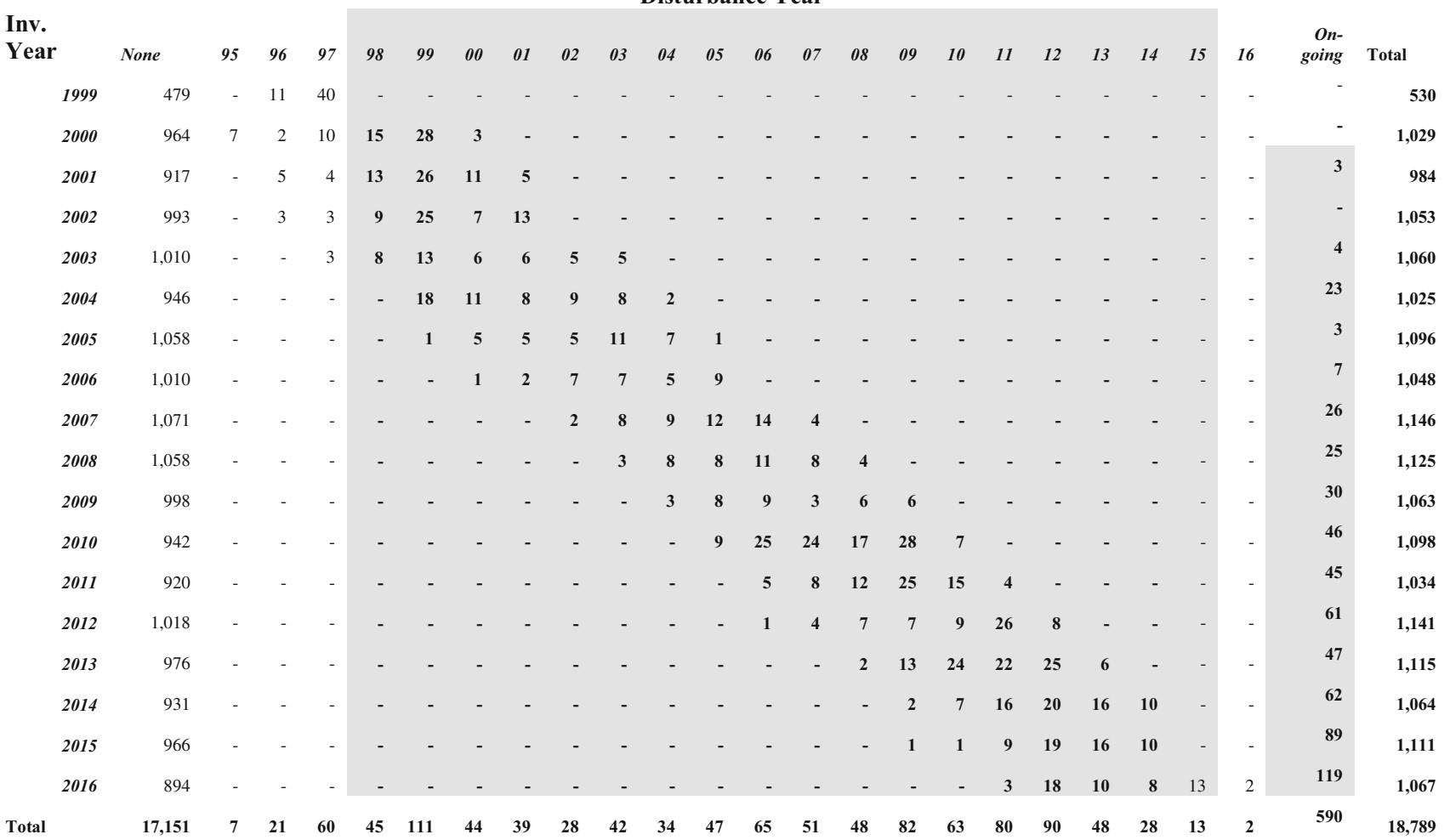

Table 5 Forestland disturbance for discrete forest cover type-disturbance type pairs ( $n \geq 5$ disturbance observations). The lower and upper $95 \%$ confidence bounds are calculated via prop.test and reported as RI.025 and RI.975

\begin{tabular}{|c|c|c|c|c|c|c|c|c|}
\hline $\begin{array}{l}\text { Forest type } \\
\text { group }\end{array}$ & $\begin{array}{l}\text { Disturbance } \\
\text { group }\end{array}$ & $\begin{array}{l}n^{*} \\
\text { (disturbed) }\end{array}$ & $\begin{array}{l}\text { Total hectares } \\
\text { disturbed }\end{array}$ & $\begin{array}{l}\text { Mean hectares } \\
\text { disturbed }\end{array}$ & RI.025 & $\begin{array}{l}\text { Return interval } \\
\text { (years) }\end{array}$ & RI.975 & $\begin{array}{l}\text { Mean cover type } \\
\text { hectares }\end{array}$ \\
\hline $\begin{array}{l}\text { White-red jack } \\
\text { pine }\end{array}$ & Fire & 11 & 20,971 & 6168 & 24.27 & 60.49 & 168.43 & 373,067 \\
\hline $\begin{array}{l}\text { White-red jack } \\
\text { pine }\end{array}$ & Weather & 15 & 21,846 & 6425 & 23.73 & 58.06 & 157.83 & 373,067 \\
\hline $\begin{array}{l}\text { White-red jack } \\
\text { pine }\end{array}$ & Human & 25 & 31,191 & 9174 & 19.26 & 40.67 & 91.86 & 373,067 \\
\hline Spruce-fir & Insect & 41 & 50,234 & 14,775 & 54.00 & 98.19 & 183.94 & $1,450,773$ \\
\hline Spruce-fir & Disease & 15 & 19,221 & 5653 & 97.76 & 256.62 & 755.34 & $1,450,773$ \\
\hline Spruce-fir & Animal & 27 & 35,612 & 10,474 & 67.99 & 138.51 & 295.95 & $1,450,773$ \\
\hline Spruce-fir & Weather & 76 & 101,978 & 29,993 & 31.94 & 48.37 & 74.18 & $1,450,773$ \\
\hline Spruce-fir & Vegetation & 9 & 11,822 & 3477 & 123.76 & 417.23 & 1775.60 & $1,450,773$ \\
\hline Spruce-fir & Human & 21 & 25,861 & 7606 & 82.78 & 190.73 & 473.55 & $1,450,773$ \\
\hline Oak-pine & Animal & 6 & 8897 & 2617 & 11.24 & 42.88 & 243.52 & 112,213 \\
\hline Oak-pine & Human & 6 & 7317 & 2152 & 12.05 & 52.14 & 379.56 & 112,213 \\
\hline Oak-hickory & Disease & 19 & 25,187 & 7408 & 45.02 & 104.48 & 262.84 & 773,990 \\
\hline Oak-hickory & Fire & 10 & 13,561 & 3989 & 62.28 & 194.05 & 733.70 & 773,990 \\
\hline Oak-hickory & Animal & 93 & 120,766 & 35,519 & 14.99 & 21.79 & 32.11 & 773,990 \\
\hline Oak-hickory & Weather & 41 & 52,095 & 15,322 & 28.22 & 50.51 & 93.33 & 773,990 \\
\hline Oak-hickory & Human & 79 & 102,386 & 30,114 & 17.08 & 25.70 & 39.28 & 773,990 \\
\hline \multirow{2}{*}{$\begin{array}{l}\text { Lowland } \\
\text { hardwoods }\end{array}$} & Insect & 9 & 12,046 & 3543 & 48.60 & 161.16 & 674.03 & 570,995 \\
\hline & Animal & 49 & 63,089 & 18,556 & 18.23 & 30.77 & 53.41 & 570,995 \\
\hline
\end{tabular}


Table 5 (continued)

\begin{tabular}{|c|c|c|c|c|c|c|c|c|}
\hline $\begin{array}{l}\text { Forest type } \\
\text { group }\end{array}$ & $\begin{array}{l}\text { Disturbance } \\
\text { group }\end{array}$ & $\begin{array}{l}n^{*} \\
\text { (disturbed) }\end{array}$ & $\begin{array}{l}\text { Total hectares } \\
\text { disturbed }\end{array}$ & $\begin{array}{l}\text { Mean hectares } \\
\text { disturbed }\end{array}$ & RI.025 & $\begin{array}{l}\text { Return interval } \\
\text { (years) }\end{array}$ & RI.975 & $\begin{array}{l}\text { Mean cover type } \\
\text { hectares* }\end{array}$ \\
\hline \multicolumn{9}{|l|}{$\begin{array}{l}\text { Lowland } \\
\text { hardwoods }\end{array}$} \\
\hline $\begin{array}{l}\text { Lowland } \\
\text { hardwoods }\end{array}$ & Weather & 79 & 101,930 & 29,979 & 12.70 & 19.05 & 29.09 & 570,995 \\
\hline $\begin{array}{l}\text { Lowland } \\
\text { hardwoods }\end{array}$ & Human & 17 & 21,650 & 6368 & 36.30 & 89.67 & 245.27 & 570,995 \\
\hline $\begin{array}{l}\text { Northern } \\
\text { hardwoods }\end{array}$ & Animal & 28 & 37,189 & 10,938 & 20.24 & 40.17 & 84.07 & 439,415 \\
\hline $\begin{array}{l}\text { Northern } \\
\text { hardwoods }\end{array}$ & Weather & 25 & 30,312 & 8915 & 23.03 & 49.29 & 112.90 & 439,415 \\
\hline $\begin{array}{l}\text { Northern } \\
\text { hardwoods }\end{array}$ & Human & 26 & 32,556 & 9575 & 22.03 & 45.89 & 101.72 & 439,415 \\
\hline Aspen-birch & Insect & 36 & 45,102 & 13,265 & 97.63 & 183.95 & 358.26 & $2,440,215$ \\
\hline Aspen-birch & Disease & 9 & 12,708 & 3738 & 201.27 & 652.87 & 2607.37 & $2,440,215$ \\
\hline Aspen-birch & Fire & 43 & 61,769 & 18,167 & 78.27 & 134.32 & 235.48 & $2,440,215$ \\
\hline Aspen-birch & Animal & 120 & 152,695 & 44,910 & 38.72 & 54.34 & 76.78 & $2,440,215$ \\
\hline Aspen-birch & Weather & 160 & 212,217 & 62,417 & 29.39 & 39.10 & 52.26 & $2,440,215$ \\
\hline Aspen-birch & Human & 121 & 150,958 & 44,399 & 39.09 & 54.96 & 77.82 & $2,440,215$ \\
\hline $\begin{array}{l}\text { Other } \\
\text { Hardwoods }\end{array}$ & Animal & 13 & 16,493 & 4851 & 5.88 & 15.45 & 49.92 & 74,953 \\
\hline $\begin{array}{l}\text { Other } \\
\text { Hardwoods }\end{array}$ & Weather & 8 & 12,814 & 3769 & 6.62 & 19.89 & 78.35 & 74,953 \\
\hline $\begin{array}{l}\text { Other } \\
\text { Hardwoods }\end{array}$ & Human & 5 & 6868 & 2020 & 8.41 & 37.11 & 295.66 & 74,953 \\
\hline Non-stocked & Animal & 5 & 6453 & 1898 & 9.91 & 46.07 & 404.19 & 87,442 \\
\hline Non-stocked & Weather & 8 & 10,002 & 2942 & 8.48 & 29.73 & 148.27 & 87,442 \\
\hline Non-stocked & Human & 8 & 10,557 & 3105 & 8.30 & 28.16 & 132.92 & 87,442 \\
\hline $\begin{array}{l}\text { Mean } \\
\quad \text { Expectation* }\end{array}$ & (1998-2014) & 1677 & $1,732,599$ & 509,588 & 12.5 & 13.16 & 13.86 & $6,709,120$ \\
\hline
\end{tabular}

*Although forest cover type-disturbance type combinations with fewer than five observations of disturbance were omitted from this summary table, those observations were included in the larger analysis and the bottom-line totals presented here

**The current summation considers only primary disturbance events (e.g., the most recent event observed) to avoid double counting and can be considered a conservative estimate based on area estimation methods described by Bechtold and Patterson (2005)

\section{References}

Aukema JE, McCullough DG, Von Holle B, Liebhold AM, Britton K, Frankel SJ (2010) Historical accumulation of nonindigenous forest pests in the continental United States. BioScience 60(11):886-897. https://doi.org/10.1525/bio.2010.60.11.5

Ayres MP, Lombardero MJ (2000) Assessing the consequences of global change for forest disturbance from herbivores and pathogens. Sci Total Environ 262(3):263-286, ISSN 0048-9697. https://doi.org/10. $1016 / \mathrm{S} 0048-9697(00) 00528-3$

Bache SM, Wickham H (2014) magrittr: a forward-pipe operator for R. R package version 1.5. https://CRAN.R-project.org/package = magrittr

Bechtold WA, Patterson PL [Editors] (2005) The enhanced forest inventory and analysis program - national sampling design and estimation procedures. Gen. Tech. Rep. SRS-80. Asheville, NC: U.S.
Department of Agriculture, Forest Service, Southern Research Station $85 \mathrm{p}$.

Bond WJ, Keeley JE (2005) Fire as a global 'herbivore': the ecology and evolution of flammable ecosystems. Trends Ecol Evol 20(7):387394

Chakraborty S, Murray GM, Magarey PA, Yonow T, Sivasithamparam K, O'Brien RG, Croft BJ, Barbetti MJ, Old KM, Dudzinski MJ, Sutherst RW, Penrose LJ, Archer C, Emmett RW (1998) Potential impact of climate change on plant diseases of economic significance to Australia. Australas Plant Pathol 27:15. https://doi.org/10.1071/ AP98001

Dale VH, Joyce LA, Mcnulty S, Neilson RP, Ayres MP, Flannigan MD, Hanson PJ, Irland LC, Lugo AE, Peterson CJ, Simberloff D, Swanson FJ, Stocks BJ, Wotton BM (2001) Climate Change and Forest Disturbances. BioScience 51(9):723-734. https://doi.org/10.1641/ 0006-3568(2001)051[0723:CCAFD]2.0.CO;2 
Frelich LE, Lorimer CG (1991) Natural disturbance regimes in hemlockhardwood forests of the Upper Great Lakes Region. Ecol Monogr 61:145-164

Frelich LE, Reich PB (1995) Spatial patterns and succession in a Minnesota southern-boreal forest. Ecol Monogr 65:325-346

Frelich LE, Reich PB (2010) Will environmental changes reinforce the impact of global warming on the prairie-forest border of central North America? Front Ecol Environ 8:371-378. https://doi.org/10. 1890/080191

Friedman SK, Reich PB (2005) Regional legacies of logging: departure from presettlement forest conditions in northern Minnesota. Ecol Appl 15:726-744. https://doi.org/10.1890/04-0748

Guyette R, Kabrick JM (2002) The legacy and continuity of forest disturbance, succession, and species at the MOFEP sites. In: Shifley, S. R.; Kabrick, J. M., eds. Proceedings of the Second Missouri Ozark Forest Ecosystem Project Symposium: Post-treatment Results of the Landscape Experiment. Gen. Tech. Rep. NC-227. St. Paul, MN: U.S. Dept. of Agriculture, Forest Service, North Central Forest Experiment Station. 26-44.

Heinselman ML (1973) Fire in the virgin forests of the Boundary Waters Canoe Area, Minnesota. Quat Res 3(3):329-382. https://doi.org/10. 1016/0033-5894(73)90003-3

Heinselman ML (1996) The boundary waters wilderness ecosystem. Regents of the University of Minnesota. University of Minnesota Press, Minneapolis and London

Henry L, Wickham H (2017) purrr: functional programming tools. R package version 0.2.3. https://CRAN.R-project.org/package=purrr

Jaakko Pöyry Consulting, Inc. (1992) Maintaining productivity and the forest resource base. A technical paper for a generic environmental impact statement on timber harvesting and forest management in Minnesota. Prepared for the Minnesota Environmental Quality Board. 305 p. plus appendices. http://conservancy.umn.edu/handle/ 11299/169578. (See Section 2.3.8 and Table 2.24)

Lesk C, Coffel E, D'Amato AW, Dodds K, Horton R (2017) Threats to North American forest: effects of species, diameter and stand age. J Ecol 95:1261-1273

Matasci G, Hermosilla T, Wulder M, White JC, Coops NC, Hobart GW, Zald HSJ (2018) Large-area mapping of Canadian boreal forest cover, height, biomass and other structural attributes using Landsat composites and lidar plots. Remote Sens Environ 209:90-106. https://doi.org/10.1016/j.rse.2018.02.046

Miles PD (2017) Forest Inventory EVALIDator web-application Version 1.6.0.03. St. Paul, MN: U.S. Department of Agriculture, Forest Service, Northern Research Station. [Available only on internet: http://apps.fs.fed.us/Evalidator/evalidator.jsp]

Müller K, Wickham H (2017) tibble: simple data frames. R package version 1.3.3. https://CRAN.R-project.org/package=tibble.

O'Connell BM; Conkling BL; Wilson AM; Burrill EA; Turner JA; Pugh SA; Christensen G; Ridley T; Menlove J (2017) The forest inventory and analysis database: database description and user guide for Phase 2 (version 7.0). U.S. Department of Agriculture, Forest Service. 830 p. [Online]. Available: https://www.fia.fs.fed.us/library/databasedocumentation/.

Pickett STA, White PS (eds) (1985) The ecology of natural disturbance and patch dynamics. Academic, New York, p 472

Porter JH, Parry ML, Carter TR (1991) The potential effects of climatic change on agricultural insect pests, In Agricultural and Forest Meteorology, Volume 57. Issues 1-3:221-240, ISSN 0168-1923. https://doi.org/10.1016/0168-1923(91)90088-8

R Core Team (2018) R: A language and environment for statistical computing. R Foundation for Statistical Computing, Vienna, Austria. URL https://www.R-project.org/.
Reilly MJ, Spies TA (2016) Disturbance, tree mortality, and implications for contemporary regional forest change in the Pacific Northwest, Forest Ecology and Management, Volume 374. Pages 15:102-110, ISSN 0378-1127. https://doi.org/10.1016/j.foreco.2016.05.002

Rich RL, Frelich LE, Reich PB (2007) Wind-throw mortality in the southern boreal forests from southern pine beetle with warming winters. Nat Clim Chang 7:713-717. https://www.nature.com/ articles/nclimate3303. https://doi.org/10.1038/nclimate3303

Rogers P (1996) Disturbance ecology and forest management: a review of the literature. Gen. Tech. Rep. INT-GTR-336. Ogden, UT: U.S. Department of Agriculture, Forest Service, Intermountain Research Station. $16 \mathrm{p}$.

RStudio Team (2016) RStudio: integrated development for R. RStudio, Inc., Boston, MA URL http://www.rstudio.com/.

Runkle JR (1982) Patterns of disturbance in some old-growth mesic forests of eastern North America. Ecology 63:1533-1546

Seidl R, Spies TA, Peterson DL, Stephens SL, Hicke JA (2016) Searching for resilience: addressing the impacts of changing disturbance regimes on forest ecosystem services. J Appl Ecol 53(1):120-129

Seidl et al (2017) Forest disturbances under climate change. Nat Clim Chang 7:395-402

Seymour RS, White AS, deMaynadier PG (2002) Natural disturbance regimes in northeastern North America - evaluating silvicultural systems using natural scales and frequencies. For Ecol Manag 155:357-367

Swift K, Ran S (2012) Successional responses to natural disturbance, forest management and climate change in British Columbia forests. J Ecosyst Man 13(1):40-62

Thom D, Seidl R (2016) Natural disturbance impacts on ecosystem services and biodiversity in temperate and boreal forests. Biol Rev Camb Philos Soc 91(3):760-781

USDA Forest Service (2001) Final environmental impact statement boundary waters canoe area wilderness fuel treatment. United States Department of Agriculture, Forest Service, Superior National Forest, Eastern Region. Milwaukee, Wisconsin. Volume 1. May, 2001.

Virtanen T, Neuvonen S (1999) Climate change and macrolepidopteran biodiversity in Finland. Chemosphere Global Change Sci 1(4):439 448, ISSN 1465-9972. https://doi.org/10.1016/S1465-9972(99) 00039-2

Vogeler JC, Braaten J, Slesak R, Falkowski MJ (2018) Extracting the full value of the Landsat archive: inter-sensor harmonization for the mapping of Minnesota's forest canopy cover (1973-2015). Remote Sens Environ 209:363-374

Welch BL (1951) On the comparison of several mean values: an alternative approach. Biometrika 38:330-336

White JC, Wulder MA, Hermosilla T, Coops NC, Hobart GW (2017) A nationwide annual characterization of 25 years of forest disturbance and recovery for Canada using Landsat time series. Remote Sens Environ 194:303-321. https://doi.org/10.1016/j.rse.2017.03.035

Wickham H (2009) ggplot2: elegant graphics for data analysis. SpringerVerlag. New York

Wickham H (2017a) tidyr: easily tidy data with 'spread()' and 'gather()' functions. R package version 0.6.3. https://CRAN.R-project.org/ package $=$ tidyr.

Wickham H (2017b) tidyverse: easily install and load 'Tidyverse' packages. R package version 1.1.1. https://CRAN.R-project.org/ package $=$ tidyverse

Wickham H, Hester J, Francois R (2017a) readr: read rectangular text data. R package version 1.1.1. https://CRAN.R-project.org/ package $=$ readr. 
Wickham H, Francois R, Henry L, Müller K (2017b) dplyr: a grammar of data manipulation. $\mathrm{R}$ package version 0.7.2. https://CRAN.Rproject.org/package $=$ dplyr.

Wilson DC, Ek AR (2018) Evidence of rapid forest change in Minnesota. Minnesota Forestry Research Notes. Department of Forest Resources, University of Minnesota, St. Paul, 55108.

Xie Y (2014) knitr: a comprehensive tool for reproducible research in R. In Victoria Stodden, Friedrich Leisch and Roger D. Peng, editors, Implementing reproducible computational research. Chapman and Hall/CRC. ISBN 978-1466561595
Xie Y (2015) Dynamic documents with R and knitr. 2nd edition. Chapman and Hall/CRC. ISBN 978-1498716963.

Xie Y (2018) knitr: a general-purpose package for dynamic report generation in R. R package version 1.20.

Publisher's note Springer Nature remains neutral with regard to jurisdictional claims in published maps and institutional affiliations. 